\title{
Effect of Pollination and Thinning Methods on Yield and Fruit Quality of Saidy Date Palms
}

Samouni, Mona T.M. ${ }^{2}$; A.M. El-Salhy ${ }^{1}$; Ibtesam F.M. Badawy ${ }^{1}$ and E.F. Ahmed ${ }^{2}$

${ }^{1}$ Dept. of Pomology, Fac. Agric., Assiut Univ., Assiut

${ }^{2}$ Central Lab. For Date Palm Res. \& Develop. Agric. Res. Centre, Giza.

Received on: $24 / 4 / 2016$

Accepted for publication on: 3/5/2016

\begin{abstract}
The effect of fruit thinning and pollen grains dusting as a pollination methods of Saidy date palm which combines of both mechanical pollination and fruit thinning were studied during 2013, 2014 and 2015 seasons. Pollen mixed with starch in ratio of $1: 1,3,5,7$ and 9 as $50,25,17,12.5$ and $10 \%$ active ingredients. Fruit thinning was carried out by 15,30 and $45 \%$ removal of setting fruits.

The obtained results indicated that there were reduction in the percentage of fruit retention and fruit weight/bunch as the pollen grains concentration was lower or fruit thinning was done. There were no significant differences in fruit weight/bunch due to dusting pollen grains powder at 50 or $25 \%$ compared to control. On other hand, there was an improve in the fruit quality in terms of increasing the fruit weight, pulp \%, total soluble solids and sugar contents and decreasing the fruit moisture content was observed with reduction of pollen grain concentrations and doing fruit thinning. Furthermore, there were no significant difference due to pollination by $17 \%$ pollen grains and removing $15 \%$ of fruit setting, as well as $12.5 \%$ pollen grains and $30 \%$ removal of setting fruit.

It could be concluded that pollination by $12.5 \%$ pollen grains powder or removing $30 \%$ of fruit setting could be a considerable yield with good fruit quality. In addition, dusting pollen grains powder at $12.5 \%$ resulted in combined of mechanical pollination and fruit thinning effects.
\end{abstract}

Keywords: Pollen grain, dusting, fruit thinning, yield, fruit quality.

\section{Introduction}

Date palm (Phoenix dactylifera L.) is a major tree crops in arid regions of the Middle East and North Africa, having an important impact on economy of many countries in these regions (FAO, 2012). Egypt is considered among the top ten date producers, Zaghloul, Samany, Hayany and Sewy are the most economically important date palm cultivars grown in Egypt. Presently, the date growers are facing may difficulties to produce high quality date fruits for economical reasons and to compete with the international market. Two of the important factors affecting fruit quality and productivity of date palm are pollination and fruit thinning. So, it is needed to find the best pollination technique that may be easiest and most convenient for improving fruiting of date palms. A research done of date palm showed that proper pollination and thinning practices are necessary to increase quantitative, qualitative and economical output of date production in palm growing (ElSalhy et al., 2010 and Iqbal et al., 2010). 
Artificial pollination is considered the only way for commercial date production. It is necessary for successful fruit set and fruiting. Mixing pollen grains with various carriers and nutrient minerals were beneficial in establishing mechanical pollination and obtaining an economical yield with good fruit quality and enhancing pollination efficiency. Mixing pollen grains with various carriers is an untraditional method in date palm pollination which combines both mechanical pollination and fruit thinning (ElKassas and Mahmoud, 1986; Mostafa, 1994; Haffer et al., 1997; ElSharabasy et al., 2003; El-Salhy et al., 2007; El-Salhy et al., 2010; Iqbal et al., 2010 and El-Salhy, 2012).

Thinning practice is an important managerial approach in date palm to improve fruit size, fruit weight, fruit quality and reduce chances of bunch breaking and alternate bearing. Several methods were used to thin date palm trees, i.e. bunch thinning, bunch strands thinning and individual fruit removal. Combination of removal of individual fruits and strands had substantially improved fruit quality (Abdel-Hamid, 2000; Ali-Dinar et al., 2002; Marashi and Mousavi, 2007 and Mostafa and El-Akkad, 2011).

Flower or fruit thinning is a critical cultural practice in the date palm production chain that affects fruit development, quality, yield and regulate the tree yearly bearing. Thinning process is generally practiced either manually or chemically. There is much concern regarding the use of chemicals on the environmental pollution and health aspects. Therefore, development of a more save and eco- nomic thinning agent for the date palm is critically required especially under harsh conditions. Fruit thinning treatments may lead to a decrease of the total yield, soluble tannins \%, crude fibers $\%$ and total acidity $\%$ and are responsible for improving the weight, size and dimensions of fruit, pulp weight $\%$, total soluble solids $\%$, total and sugar contents (Khalifa et al., 1987; Awad, 2006 and AbdelGalil et al., 2008). Thinning by removing $10-30 \%$ of bunches number significantly increased the bunch weight, advancing ripening and best fruit quality compared to unthinning (Godara et al., 1990; El-Shazly, 1999; Abdel-Hamid, 2000; Akl et al., 2004; El-Assar, 2005; Al-Wasfy \& Mostafa, 2008 and Mostafa \& ElAkkad, 2011).

So, it is needed to find the best pollination technique that most convenient easiest and was act a thinning effects to get the economical yield with best fruit quality.

The, this study aimed to find out the effect of different methods of pollination and fruit thinning on yield and fruit quality. In addition to innovating an untraditional pollination method which combines both mechanical pollination and fruit thinning. Such practices might be very essential and great importance for palm growers.

\section{Materials and Methods}

This study was carried out during three successive seasons 2013, 2014 and 2015 on Saidy date palms grown at Research Farm of Agricultural Research Station that located at El-Kharga Oasis, New Valley Governorate, Egypt. Ten palms of 35 years old, with uniform vigour and in good 
physical condition, free of insect damage and diseases. The number of spathes per palm were adjusted to ten by removing excess earliest, latest and smallest. The retained bunches were thinned to a constant number of strands. The involved palm trees received the horticulture practices. Nine pollination and fruit thinning treatments were arranged as follows:

1-Hand pollination by inserting 7-10 strands/bunch $\left(\mathrm{T}_{1}\right)$.

2-Dusting mixed pollen grains at 1 unit of pollen to 1 unit starch (50\% active ingredients) on a volume basis $\left(\mathrm{T}_{2}\right)$.

3-Dusting mixed pollen grains at 1 unit of pollen to 3 units starch ( $25 \%$ active ingredients) on a volume basis $\left(\mathrm{T}_{3}\right)$.

4-Dusting mixed pollen grains at 1 unit of pollen to 5 units starch (17\% active ingredients) on a volume basis $\left(\mathrm{T}_{4}\right)$.

5-Dusting mixed pollen grains at 1 unit of pollen to 7 units starch (12.5\% active ingredients) on a volume basis $\left(\mathrm{T}_{5}\right)$.

6-Dusting mixed pollen grains at 1 unit of pollen to 9 units starch ( $10 \%$ active ingredients) on a volume basis $\left(\mathrm{T}_{6}\right)$.

7-Thinning by removing $15 \%$ of the fruits per strands $\left(\mathrm{T}_{7}\right)$.

8 -Thinning by removing $30 \%$ of the fruits per strands $\left(T_{8}\right)$.

9 -Thinning by removing $45 \%$ of the fruits per strands $\left(\mathrm{T}_{9}\right)$.

The pollen grains were extracted by removing protective sheath and inflorescence was kept under sunlight on newspaper for releasing pollen grains. After one hour the flowers were open and pollen grains released. After drying pollen grains were rubbed in foam duster. Dusting was done on opened spathe. To prevent contamination of pollens, after pollination every bunch was bagged by paper bags which is removed after fruit set.

Pollination was uniformed in respect of source date and method to avoid residues of metaxenia, as well as Fruit thinning treatments were done after fruit set and applied on the same palm.

The experiment was arranged in a complete randomized block design including nine treatments with ten replications, bunch each.

All bunches were harvested at tamr stage (last week of September) ultimate fruit retention and fruit weight/bunch $(\mathrm{kg})$ were estimated. Samples of 50 fruits were picked at random from each bunch for the determination of some physical and chemical fruit properties, according to A.O.A.C. methods (1985). Data were subjected to statistical analysis according to the procedure reported by Gomez and Gomez (1984) and Snedecor and Cochran (1990). Treatments means were compared by the least significant difference test (L.S.D.) at the $5 \%$ level of probability in the three experimental seasons.

\section{Results and Discussion}

\section{Yield index:}

Bunch weight is an indicator for the yield of palm trees since the number of bunches on palm was constant. Table (1) exhibits the effect of pollination and fruit thinning treatments on the fruit retention and fruit weight/bunch of Saidy date palm in 2013,2014 \& 2015 seasons. it is obvious from the data that the results took similar trend during the three 
studied seasons. Data declared that, fruit retention percentage and fruit weight/bunch were significantly decreased due to pollinating by dusting pollen grain with starch at 1 pollen to $5\left(\mathrm{~T}_{4}\right), 7\left(\mathrm{~T}_{5}\right)$ or $9\left(\mathrm{~T}_{6}\right)$ starch $(17$, 12.5 or $10 \%$ pollen) as well as doing fruit thinning compared with the traditional pollination. On other hand data, showed that insignificant difference in fruit reduction and fruit weight/bunch due to dust pollen powder at 1 pollen to 1 starch $\left(\mathrm{T}_{2}\right)$ or 3 starch $\left(\mathrm{T}_{3}\right)$ (50 or $25 \%$ active ingredients on volume basis).

Also, no significant difference in these traits due to dusting by $17 \%$ pollen grains $\left(T_{4}\right)$ and fruit thinning by removing $15 \%$ of fruits $\left(\mathrm{T}_{7}\right)$, as well as dusting by $12.5 \%$ pollen grains $\left(\mathrm{T}_{5}\right)$ and fruit thinning by removing $30 \%$ of fruits $\left(T_{8}\right)$.

The fruit retention percentage were $(79.10,77.65,76.48,65.25$,
$55.10, \quad 34.88, \quad 68.60, \quad 57.13$ and $45.59 \%$ as av. of the three studied seasons) due to pollinating by traditional pollination $\left(\mathrm{T}_{1}\right)$, dusting pollen with starch at $\left(50 \%, \mathrm{~T}_{2}\right), 1: 3(25 \%$, $\left.\mathrm{T}_{3}\right), 1: 5\left(17 \%, \mathrm{~T}_{4}\right), 1: 7\left(12.5 \%, \mathrm{~T}_{5}\right)$, $1: 8\left(10 \%, \mathrm{~T}_{6}\right), 15 \%$ thinning $\left(\mathrm{T}_{7}\right), 30$ thinning $\left(\mathrm{T}_{8}\right)$ and $45 \%$ thinning $\left(\mathrm{T}_{5}\right)$, respectively. The corresponding fruit weight/bunch were $(11.30,10.95$, $10.80,10.30,9.20,6.58,10.32,9.55$ and $8.17 \mathrm{~kg}$ ) due to use of $\mathrm{T}_{1}$ to $\mathrm{T}_{9}$, respectively. The decrement percentage of fruit weight/bunch due to dust pollen powder or fruit thinning over traditional pollination and unthinned fruits $\left(\mathrm{T}_{1}\right)$ were $(3.10,4.42,8.85$, $18.58,41.77,8.67,8.45$ and $27.70 \%$ as av. of the three studied seasons) due to $T_{2}$ to $T_{9}$ compared to $T_{1}$, respectively.

Table 1. Effect of pollination and fruit thinning treatments on fruit retention and fruit weight/bunch of Saidy date during 2013, 2014 and 2015 seasons.

\begin{tabular}{|l|c|c|c|c|c|c|c|c|c|}
\hline \multirow{2}{*}{} & & \multicolumn{3}{|c|}{ Fruit retention (\%) } & \multicolumn{3}{c|}{ Fruit weight/bunch (kg) } \\
\cline { 3 - 10 } & & $\mathbf{2 0 1 3}$ & $\mathbf{2 0 1 4}$ & $\mathbf{2 0 1 5}$ & Mean & $\mathbf{2 0 1 3}$ & $\mathbf{2 0 1 4}$ & $\mathbf{2 0 1 5}$ & Mean \\
\hline Hand pollination. & $\mathbf{T}_{\mathbf{1}}$ & 75.30 & 76.64 & 85.35 & 79.10 & 11.22 & 11.69 & 11.00 & 11.30 \\
\hline Dusting (50\% pollen) & $\mathbf{T}_{\mathbf{2}}$ & 73.85 & 75.18 & 83.90 & 77.65 & 10.84 & 11.38 & 10.65 & 10.95 \\
\hline Dusting (25\% pollen) & $\mathbf{T}_{\mathbf{3}}$ & 72.70 & 73.88 & 82.74 & 76.48 & 10.70 & 11.28 & 10.42 & 10.80 \\
\hline Dusting (17\% pollen) & $\mathbf{T}_{\mathbf{4}}$ & 61.80 & 62.74 & 71.22 & 65.25 & 10.10 & 10.85 & 9.94 & 10.30 \\
\hline Dusting (12.5\% pollen) & $\mathbf{T}_{\mathbf{5}}$ & 52.60 & 52.86 & 59.85 & 55.10 & 9.17 & 9.52 & 8.92 & 9.20 \\
\hline Dusting (10\% pollen) & $\mathbf{T}_{\mathbf{6}}$ & 33.70 & 34.25 & 36.68 & 34.88 & 6.55 & 6.92 & 6.26 & 6.58 \\
\hline Thinning (15\% fruits) & $\mathbf{T}_{\mathbf{7}}$ & 66.76 & 66.39 & 72.65 & 68.60 & 9.95 & 10.15 & 10.85 & 10.32 \\
\hline Thinning (30\% fruits) & $\mathbf{T}_{\mathbf{8}}$ & 53.38 & 52.78 & 65.11 & 57.13 & 9.10 & 9.30 & 10.25 & 9.55 \\
\hline Thinning (45\% fruits) & $\mathbf{T}_{\mathbf{9}}$ & 45.50 & 43.35 & 47.92 & 45.59 & 7.95 & 7.80 & 8.75 & 8.17 \\
\hline L.S.D. & & $\mathbf{3 . 8 1}$ & $\mathbf{3 . 7 0}$ & $\mathbf{4 . 1 0}$ & $\mathbf{3 . 1 1}$ & $\mathbf{0 . 5 9}$ & $\mathbf{0 . 5 5}$ & $\mathbf{0 . 6 1}$ & $\mathbf{0 . 5 3}$ \\
\hline
\end{tabular}

The reduction on fruit weight / bunch was associated with decreasing the pollen grain percentage from 50 to $10 \%$ as well as fruit thinning from 15 to $45 \%$ of fruit set. These results could be attributed to the reduction of fruit set because of decreasing the pollen grain concentration as well as reducing the fruit retention, hence, the fruit weight/bunch was decreased. Then, it could be concluded that there was a significant positive correlation between the fruit retention and fruit weight/bunch. 
Such a finding might be attributed to the pollen grains that have different sensitivities during pollen tube growth on stigmas. Higher pollen concentration resulted in more initial fruit set due to the pollination of a larger number of available female flowers. The mixed carriers on reducing fruit set might be due to low pollen concentration as well as the carrier either decrease the moisture absorption around the stigma or their competition with pollen grains on stigmas.

It can be concluded from these results that using dusting, had proved important from economic point of view which are shown 12.5 to $25 \%$ from the need amount of traditional pollination without reduction on yield.

\section{Fruit quality:}

\section{A- Physical characteristics:}

Data in Tables $(2 \& 3)$ indicated that there was an improvement of the fruit physical quality in terms of increasing the fruit weight, size dimensions and fruit pulp percentage and decreasing moisture content due to pollination with dusting methods or fruit thinning compared to the traditional pollination (control). The improving of these traits was associated with the decrease of the used pollen grains concentration from $25-10 \%$ as well as retained fruits from 85 to $55 \%$ of setting fruits. The heaviest fruits were detected on palms pollinated with pollen grain concentration at $10 \%$ of dusting powder $\left(\mathrm{T}_{6}\right)$, as well as removing $45 \%$ of setting fruit $\left(\mathrm{T}_{\mathbf{9}}\right)$. No significant differences in fruit weight, dimensions, fruit pulp $\%$ and moisture content were observed due to using dusting of pollen grains at 10 or $12.5 \%$ as well as fruit thinning by removing 30 to $45 \%$ of setting fruits.

The recorded fruit weight were 8.64, 8.72, 8.82, 9.57, 10.97, 11.23, $10.08,11.14$ and $11.40 \mathrm{~g}$ (average of the three studied seasons) due to $T_{1}$ to $\mathrm{T}_{9}$, respectively. The increment percentage of fruit weight in response to different pollination and fruit thinning treatments over control $\left(\mathrm{T}_{1}\right)$ were $0.92,2.08,10.76,26.97,29.98$, $16.67,28.94$ and $31.94 \%$ (average of the three studied seasons) due to $T_{2}$ to $\mathrm{T}_{9}$ respectively.

The increase in fruit weight and its size are most important target than total yield due to the increase of fruit weight and size resulted in an increase in the packable yield.

Such improvement of fruit physical properties i.e. increasing fruit weight, dimension and pulp \% might be occurred in response to the use of diluted pollen grains dusting for pollination. These findings could be due to the reduction of fruit retention that cause a reduction in the number of fruits per bunch without changing the number of leaves that may induce the better supply of carbohydrates which are synthesized in the leaves. Such effects were similar to fruit thinning effects on improving the physical fruit properties. So, it could be easy to identify the initial fruit set percentage which gave the considerable yield characterized by high fruit quality using either different hand pollination techniques dusting pollens or fruit thinning methods.

\section{B-Chemical characteristics:}

Data in Tables $(4 \& 5)$ indicated that pollination by pollen grains dusting or fruit thinning were significantly improved the fruit chemical consti- 
tuents in terms of increasing the soluble solids and sugar contents compared to pollination by traditional pollination. The improvement of these fruit traits was associated with the reduction of pollen grain concentration from 25 to $10 \%$ as well as retained fruits from $85-55 \%$ of setting fruits or pollen powder dusting at $10 \%$ pollen $\left(\mathrm{T}_{6}\right)$ as well as removing
$45 \%$ of setting fruit $\left(\mathrm{T}_{9}\right)$ gave the maximum values of soluble solids and sugar contents, whereas, using the traditional pollination $\left(\mathrm{T}_{1}\right)$ gave the minimum values. No significant difference in fruit chemical properties were observed due to use of either dusting pollen at $10-12.5 \%$ or removing $30-45 \%$ of setting fruits.

Table 2. Effect of pollination and fruit thinning treatments on fruit weight and dimension of Saidy date during 2013, 2014 and 2015 seasons.

\begin{tabular}{|c|c|c|c|c|c|c|c|c|c|c|c|c|}
\hline \multirow{2}{*}{$\begin{array}{c}\text { Charac. } \\
\text { Treat. }\end{array}$} & \multicolumn{4}{|c|}{ Fruit weight (g) } & \multicolumn{4}{c|}{ Fruit length (cm) } & \multicolumn{3}{c|}{ Fruit diameter (cm) } \\
\hline & $\mathbf{2 0 1 3}$ & $\mathbf{2 0 1 4}$ & $\mathbf{2 0 1 5}$ & Mean & $\mathbf{2 0 1 3}$ & $\mathbf{2 0 1 4}$ & $\mathbf{2 0 1 5}$ & Mean & $\mathbf{2 0 1 3}$ & $\mathbf{2 0 1 4}$ & $\mathbf{2 0 1 5}$ & Mean \\
\hline $\mathbf{T}_{\mathbf{1}}$ & 8.68 & 8.71 & 8.52 & 8.64 & 3.39 & 3.42 & 3.36 & 3.39 & 2.10 & 2.11 & 2.10 & 2.10 \\
\hline $\mathbf{T}_{\mathbf{2}}$ & 8.76 & 8.80 & 8.60 & 8.72 & 3.43 & 3.44 & 3.39 & 3.42 & 2.11 & 2.13 & 2.12 & 2.12 \\
\hline $\mathbf{T}_{\mathbf{3}}$ & 8.87 & 8.85 & 8.75 & 8.82 & 3.52 & 3.55 & 3.50 & 3.52 & 2.12 & 2.13 & 2.12 & 2.12 \\
\hline $\mathbf{T}_{\mathbf{4}}$ & 9.65 & 9.67 & 9.40 & 9.57 & 3.58 & 3.59 & 3.54 & 3.57 & 2.24 & 2.25 & 2.23 & 2.24 \\
\hline $\mathbf{T}_{\mathbf{5}}$ & 10.97 & 11.10 & 10.86 & 10.97 & 3.78 & 3.81 & 3.76 & 3.78 & 2.26 & 2.28 & 2.25 & 2.26 \\
\hline $\mathbf{T}_{\mathbf{6}}$ & 11.20 & 11.40 & 11.10 & 11.23 & 3.98 & 4.07 & 3.82 & 3.96 & 2.28 & 2.31 & 2.26 & 2.28 \\
\hline $\mathbf{T}_{\mathbf{7}}$ & 10.05 & 10.15 & 10.05 & 10.08 & 3.66 & 3.70 & 3.65 & 3.67 & 2.14 & 2.16 & 2.25 & 2.18 \\
\hline $\mathbf{T}_{\mathbf{8}}$ & 11.24 & 11.20 & 10.99 & 11.14 & 4.00 & 3.94 & 3.82 & 3.92 & 2.21 & 2.25 & 2.32 & 2.26 \\
\hline $\mathbf{T}_{\mathbf{9}}$ & 11.39 & 11.47 & 11.35 & 11.40 & 4.01 & 4.01 & 3.94 & 3.99 & 2.23 & 2.25 & 2.34 & 2.27 \\
\hline L.S.D. & $\mathbf{0 . 5 3}$ & $\mathbf{0 . 5 8}$ & $\mathbf{0 . 5 1}$ & $\mathbf{0 . 4 4}$ & $\mathbf{0 . 1 7}$ & $\mathbf{0 . 1 5}$ & $\mathbf{0 . 1 5}$ & $\mathbf{0 . 1 3}$ & $\mathbf{0 . 0 9}$ & $\mathbf{0 . 1 0}$ & $\mathbf{0 . 0 8}$ & $\mathbf{0 . 0 6}$ \\
\hline
\end{tabular}

Table 3. Effect of pollination and fruit thinning treatments on pulp weight and moisture percentage of Saidy date during 2013, 2014 and 2015 seasons.

\begin{tabular}{|c|c|c|c|c|c|c|c|c|}
\hline \multirow{2}{*}{$\begin{array}{c}\text { Charac. } \\
\text { Treat. }\end{array}$} & \multicolumn{4}{|c|}{ Pulp weight (\%) } & \multicolumn{4}{c|}{ Fruit moisture (\%) } \\
\cline { 2 - 9 } & $\mathbf{2 0 1 3}$ & $\mathbf{2 0 1 4}$ & $\mathbf{2 0 1 5}$ & Mean & $\mathbf{2 0 1 3}$ & $\mathbf{2 0 1 4}$ & $\mathbf{2 0 1 5}$ & Mean \\
\hline $\mathbf{T}_{\mathbf{1}}$ & 84.49 & 84.62 & 84.51 & 84.54 & 15.00 & 14.80 & 14.00 & 14.60 \\
\hline $\mathbf{T}_{\mathbf{2}}$ & 84.60 & 84.80 & 84.76 & 84.72 & 14.86 & 14.65 & 13.85 & 14.45 \\
\hline $\mathbf{T}_{\mathbf{3}}$ & 84.78 & 84.86 & 84.80 & 84.81 & 14.45 & 14.65 & 14.00 & 14.37 \\
\hline $\mathbf{T}_{\mathbf{4}}$ & 86.44 & 86.54 & 86.65 & 86.54 & 13.50 & 13.75 & 13.50 & 13.72 \\
\hline $\mathbf{T}_{\mathbf{5}}$ & 87.25 & 87.44 & 87.43 & 87.37 & 13.10 & 13.25 & 12.90 & 13.08 \\
\hline $\mathbf{T}_{\mathbf{6}}$ & 87.72 & 88.22 & 87.98 & 87.97 & 12.10 & 12.90 & 12.85 & 12.82 \\
\hline $\mathbf{T}_{\mathbf{7}}$ & 85.71 & 87.35 & 86.95 & 87.27 & 13.75 & 13.75 & 13.50 & 13.67 \\
\hline $\mathbf{T}_{\mathbf{8}}$ & 87.52 & 88.48 & 87.28 & 88.13 & 13.25 & 13.30 & 13.05 & 13.20 \\
\hline $\mathbf{T}_{\mathbf{9}}$ & 88.72 & 88.63 & 88.13 & 88.49 & 12.80 & 12.95 & 12.75 & 12.83 \\
\hline L.S.D. & $\mathbf{1 . 8 5}$ & $\mathbf{1 . 9 0}$ & $\mathbf{1 . 8 8}$ & $\mathbf{1 . 6 3}$ & $\mathbf{0 . 5 6}$ & $\mathbf{0 . 5 3}$ & $\mathbf{0 . 3 8}$ & $\mathbf{0 . 4 2}$ \\
\hline
\end{tabular}


Table 4. Effect of pollination and fruit thinning treatments on total soluble acids and total sugars contents of Saidy date during 2013, 2014 and 2015 seasons.

\begin{tabular}{|c|c|c|c|c|c|c|c|c|}
\hline \multirow{2}{*}{ Charac. } & \multicolumn{4}{|c|}{ TSS (\%) } & \multicolumn{4}{c|}{ Total sugars (\%) } \\
\cline { 2 - 9 } Treat. & $\mathbf{2 0 1 3}$ & $\mathbf{2 0 1 4}$ & $\mathbf{2 0 1 5}$ & Mean & $\mathbf{2 0 1 3}$ & $\mathbf{2 0 1 4}$ & $\mathbf{2 0 1 5}$ & Mean \\
\hline $\mathbf{T}_{\mathbf{1}}$ & 74.50 & 75.70 & 74.00 & 74.73 & 69.43 & 69.30 & 67.48 & 68.74 \\
\hline $\mathbf{T}_{\mathbf{2}}$ & 75.10 & 76.20 & 74.54 & 75.28 & 69.95 & 69.85 & 68.10 & 69.30 \\
\hline $\mathbf{T}_{\mathbf{3}}$ & 75.60 & 76.40 & 75.42 & 75.81 & 70.32 & 70.04 & 68.86 & 69.74 \\
\hline $\mathbf{T}_{\mathbf{4}}$ & 77.30 & 78.10 & 76.24 & 77.21 & 71.57 & 71.75 & 69.86 & 71.06 \\
\hline $\mathbf{T}_{\mathbf{5}}$ & 78.80 & 80.60 & 78.50 & 79.30 & 73.21 & 73.96 & 71.67 & 72.95 \\
\hline $\mathbf{T}_{\mathbf{6}}$ & 79.90 & 81.10 & 79.50 & 80.17 & 73.36 & 74.26 & 71.88 & 73.17 \\
\hline $\mathbf{T}_{\mathbf{7}}$ & 78.88 & 79.40 & 77.77 & 78.68 & 72.57 & 73.40 & 72.00 & 72.66 \\
\hline $\mathbf{T}_{\mathbf{8}}$ & 80.08 & 80.52 & 79.40 & 79.97 & 73.72 & 74.47 & 73.14 & 73.78 \\
\hline $\mathbf{T}_{\mathbf{9}}$ & 81.04 & 81.80 & 80.48 & 81.11 & 74.95 & 75.44 & 74.46 & 74.95 \\
\hline L.S.D. & $\mathbf{2 . 2 8}$ & $\mathbf{2 . 3 6}$ & $\mathbf{2 . 0 5}$ & $\mathbf{1 . 9 6}$ & $\mathbf{2 . 4 4}$ & $\mathbf{2 . 7 4}$ & $\mathbf{2 . 4 3}$ & $\mathbf{2 . 2 4}$ \\
\hline
\end{tabular}

Table 5. Effect of pollination and fruit thinning treatments on reducing and nonreducing contents of Saidy date during 2013, 2014 and 2015 seasons.

\begin{tabular}{|c|c|c|c|c|c|c|c|c|}
\hline \multirow{2}{*}{$\begin{array}{c}\text { Charac. } \\
\text { Treat. }\end{array}$} & \multicolumn{4}{|c|}{ Reducing sugars (\%) } & \multicolumn{3}{c|}{ Non-reducing sugars (\%) } \\
\cline { 2 - 9 } & $\mathbf{2 0 1 3}$ & $\mathbf{2 0 1 4}$ & $\mathbf{2 0 1 5}$ & Mean & $\mathbf{2 0 1 3}$ & $\mathbf{2 0 1 4}$ & $\mathbf{2 0 1 5}$ & Mean \\
\hline $\mathbf{T}_{\mathbf{1}}$ & 60.77 & 60.98 & 59.38 & 60.38 & 8.66 & 8.32 & 8.10 & 8.36 \\
\hline $\mathbf{T}_{\mathbf{2}}$ & 61.20 & 61.38 & 60.25 & 60.94 & 8.75 & 8.47 & 7.85 & 8.36 \\
\hline $\mathbf{T}_{\mathbf{3}}$ & 61.34 & 61.64 & 60.60 & 61.19 & 8.98 & 8.41 & 8.26 & 8.55 \\
\hline $\mathbf{T}_{\mathbf{4}}$ & 62.10 & 63.14 & 61.25 & 62.16 & 9.47 & 8.61 & 8.61 & 8.90 \\
\hline $\mathbf{T}_{\mathbf{5}}$ & 63.38 & 65.51 & 62.99 & 63.79 & 9.83 & 8.76 & 8.68 & 9.16 \\
\hline $\mathbf{T}_{\mathbf{6}}$ & 63.30 & 65.35 & 63.25 & 63.97 & 10.06 & 8.91 & 8.63 & 9.20 \\
\hline $\mathbf{T}_{\mathbf{7}}$ & 62.95 & 63.42 & 63.64 & 63.34 & 9.62 & 9.98 & 8.36 & 9.40 \\
\hline $\mathbf{T}_{\mathbf{8}}$ & 63.42 & 64.31 & 64.19 & 63.97 & 10.30 & 10.16 & 8.95 & 9.80 \\
\hline $\mathbf{T}_{\mathbf{9}}$ & 64.71 & 65.12 & 65.35 & 65.06 & 10.24 & 10.32 & 9.11 & 9.89 \\
\hline L.S.D. & $\mathbf{1 . 8 9}$ & $\mathbf{1 . 8 0}$ & $\mathbf{1 . 7 8}$ & $\mathbf{1 . 6 1}$ & $\mathbf{0 . 4 1}$ & $\mathbf{0 . 3 8}$ & $\mathbf{0 . 2 9}$ & $\mathbf{0 . 3 3}$ \\
\hline
\end{tabular}

The obtained total soluble solids (TSS) were (74.73, 75.28, 75.81, $77.21,79.30,80.17,78.68,79.97$ and 81.11 as av. the three studied seasons) due to $T_{1}$ to $T_{9}$, respectively. The increment percentage of TSS due pollen dusting or fruit thinning was attained $(0.73,1.45,3.32,6.12,7.28$, $5.29,7.01$ and $8.54 \%$ as av. the three studied seasons) due to $\mathrm{T}_{2}$ to $\mathrm{T}_{9}$ compared to $T_{1}$, respectively.

These findings might be due to the reduction in the fruit retention percentage by using the diluted pollen grain concentration or remained fruits due to fruit thinning. Such reduction in fruits was effective on lowering the competition among the fruits and induces adequate carbohydrates and other essentials assimilated for the residual ones, which consequently enhance the fruit maturity and improves its contents of total soluble solids and sugar contents. In addition, fruit thinning, effectively lowered the competition occurred between fruits and consequently raised the total soluble solids and sugar contents for each fruit. So, it could be said that the use of diluted pollen grain concentra- 
tion has a similar effect like the fruit thinning on improving the fruit quality.

In general, it could be concluded that there is a positive relationship between fruit thinning and improvement of physical quality and the chemical constituents. On other hand, there is a negative relationship between the fruit retention and improvement of fruit quality.

These results are in harmony with the results of Haffer et al. (1997), Khayyat et al. (2007), ElSalhy et al. (2007), Ashour et al. (2008), Alabri et al. (2006), El-Salhy et al. (2010), El-Sese et al. (2010), Iqbal et al. (2010), Abdalla et al. (2011) and El-Salhy et al. (2012).

In addition, the enhancing effect of fruit thinning on date fruiting are in harmony with the results obtained by Godara (1990), Moustafa (1998), El-Shazly (1999), Abdel-Hamid (2000), Hussein \& Hassan (2001), Hammam et al. (2002), Nirmaljit et al. (2006), Tavakkoli et al. (2006), Marzouk et al. (2007), Marashi \& Mousavi (2007), Al-Wasfy \& Mostafa (2008), Abdel-Galil et al. (2008), Mostafa \& El-Akkad (2011), Damankeshan \& Panahi (2013), Bashir et al. (2014) and Al-Saikhan \& Sallam (2015).

\section{Conclusion}

On the light of the current results, it could be concluded that pollination by $12.5 \%$ pollen grains powder or fruit thinning by remaining $30 \%$ of fruits setting could lead to a considerable yield with good fruit quality. In addition, dusting pollen grains powder at $12.5 \%$ play a combined mechanical pollination and fruit thinning effects.

\section{References}

A.O.A.C. (1985). Association of Official Agricultural Chemists. Official Methods of Analysis. A.O.A.C. $14^{\text {th }}$ Ed. Published by A.O.A.C. Washington, D.C. (U.S.A.).

Abdalla, M.G.; A.M. EL-Salhy and R.A.A. Mostafa (2011). Effect of some pollination treatments on fruiting of Zaghloul date palm cultivars under Assiut climatic conditions. Assiut J. of Agric. Sci, 42 (special issue) 350-362.

Abdel-Galil, H.A.; A.M. El-Salhy; M.M. El-Akkad and Y.M. Diab (2008). Effect of different methods and dates of fruit thinning on "Sewy" date yield and quality under New Valley conditions. The 3rd Int. Conf. on Date Palm, 25-27 April, El-Arish, Egypt.

Abdel-Hamid, N. (2000). Effect of time, rate and patterns of thinning, leaf bunch ratio and male type on "Zaghloul" date yield and quality. Arab, J. Agric. Sci. Ain Shams Univ., Cairo, 8(1): 305317.

Akl, A.M.; M.A. Ragab and A.Y. Mohamed (2004). Yield and fruit quality of Sewy date palms in response to some fruit thinning treatments. The Second Inter. Conf. on Date Palm Faculty of Envir. Agric. Sci., El-Arish, Suez Canal Univ. Egypt. 6-8 Oct.

Alabri, N.; K. Al-Busaidi and S. Alhemaimee (2006). Effect of pollen grains suspension on fruit set and physicochemical characteristics of two date palm (Phoenix dactylifera.) cultivar Qnt. Conf. on date palm production and processing technology May 9-11 Muscat, Oman. P19 
Ali-Dinar, H.M.; A.A. Alkhateeb; I. Al-Abdulhadi; A. Alkhateeb; K.A. Abugulia and G.R. Abdulla (2002). Bunch thinning improves yield and fruit quality of date palm (Phoenix dactylifera L.). Egypt. J. Applied Sci., 17 (11): 228-238.

Al-Saikhan, M.S. and A.A. Sallam (2015). Impact of chemical and non-chemical thinning treatment on yield and fruit quality of date palm. J. of Food and Research, 4 (4): 18-24.

Al-Wasfy, M.M. and R.A.A. Mostafa (2008). Effect of different methods of fruit thinning on Zaghloul date palm production and fruit quality. Assiut J. of Agric. Sci., 39(1): 97-106.

Ashour, N.E.; H.S.A. Hassan and E.A.M. Mostafa (2008). Effect of some pollen carriers on yield and fruit quality of Zaghloul and Samani date palm cultivars. American-Eurasian J. Agric. \& Environ. Sci., 4(3): 391-396.

Awad, A.M. (2006). Water spray as a potential thinning agent for date palm flowers (Phoenix dactylife$r a$ L.) c.v. "Lulu" Abstract J. Int. Conf. on Date Palm Production and Processing Technology, May 9-11, Muscat Oman, p: 12.

Bashir, M.A.; M. Ahmad; F. Altaf and K. Shabir (2014). Fruit quality and yield of date palm (Phoenix dactylifera L.) as affected by strand thinning. J. Anim. Plant Sci., 24 (3): 951-954.

Damankeshan, B. and B. Panahi (2013). Evaluation of the effects of bunch thinning methods on drying blossom of date palm disorder in two stages of pollination and Kimri. Inter. Res. Of Appl. Basic. Sci. 4 (6): 1514-1516.
El-Assar, A.M. (2005). Response of "Zaghloul" date yield and fruit characteristics to various organic and inorganic fertilization types as well as fruit thinning models in a rich carbonate soil. J. Agric. Sci. Mansoura Univ., 30(5): 2795-2814.

El-Kassas, Sh.E. and H.M. Mahmoud (1986). The possibility of pollinating date palm by diluted pollen. Proceeding of second Symposium on date palm in Saudi Arabia, Al-Hassa, Saudi Arabia.

El-Salhy, A., H.M. Marzouk, H.A. Abdel-Galil and A.E. Mahmoud (2007). Effect of some pollination treatments on yield and fruit quality of some date palm cultivars. The $4^{\text {th }}$ Symposium on date palm in Saudi Arabia, King Faisal Univ., Al-Hassa, 5-8 May.

El-Salhy, A.; H.A. Abdel-Galil; A.A. El-Bana and E.F. Ahmed (2010). Effect of pollen grains suspensions spraying on yield and fruit quality of Saidy date palm cultivar. Acta Horti. 882 Dec. 329336 Pro. of $4^{\text {th }}$ Iner. Date Palm Con.

El-Salhy, A.M.; R.A.A. Mostafa; A.A. El-Banna and Y.M. Diab (2012). Effect of pollination methods and pollen grains dilution on bunch weight and fruit quality of Sewy date palm cultivar. Assiut J. Agric. Sci., 43, No. 2 (Special Issue): 119-131.

El-Sese, A.M.A.; A.K.A. Mohamed and M.T.M. Samouni (2010). Effect of pollen grains concentration on bunch weight and fruit quality of Halawy and Hayany date palm cultivars. Zagazig J. Agric. Res., 37 (1): 17-39.

El-Sharabasy, S., A. Seif Eldin, A. Banna and A.A. Eliwa (2003). 
Effect of pollination methods and pollen sources on fruit set, yield and fruit quality of Sewy and Samany dates. J. Agric. Sci. Mansoura Univ., 28 (6): 48574870, Egypt.

El-Shazly, S.M. (1999). Effect of fruit thinning on yield and fruit quality of "Nabtet Ali" Saudi date palm. The International Conference on date palm Nov. 9-11, Assiut Univ., Egypt, pp: 17-33.

FAO (2012). Food and Agriculture Organization Statistical Year Book. FAO. Rome Italy.

Godara, R.K.; N.R. Godara and N.S. Nehra (1990). Effect of level of thinning on ripening of date palm fruit (Phoenix dactylifera) cv. Shamran. Res. Dev. Rep., 7(1-2): 21-25.

Gomez, K.A. and A.A. Gomez (1984). Statistical Procedures for Agriculture Research. 2nd Ed. Wily, New York.

Haffer, I., H. Al-Jubuiri and M.H. Ahmed (1997). Effect of pollination frequency and pollen concentration on yield and fruit of mechanical pollinated date palm trees (Phoenix dactylifera L.). J. Agric. Engn. Res. 68: 11-14.

Hammam, M.S.; Sabour-Asma and Ebeed-Sanaa (2002). Effect of some fruit thinning treatments on yield and fruit quality of Zaghloul date palm. Arab Univ. J. Agric. Sci., Ain Shams Univ., Cairo, 10(1): 261-271.

Hussein, F.H. and A.S. Hassan (2001). Effect of hand and mechanical pollination on fruit set, yield and fruit quality of dry dates CV. "Gondeila" under conditions of Aswan Governorate, Egypt. Zagazig J. Agric. Res., 28 (6): 1035-1049.
Hussein, F.H. and A.S. Hassan (2001). Effect of hand and mechanical pollination on fruit set, yield and fruit quality of dry dates $\mathrm{CV}$. "Gondeila" under conditions of Aswan Governorate, Egypt. Zagazig J. Agric. Res., 28 (6): 1035-1049.

Iqbal, M; M.Q. Khan; M. Munir; S. Rehman; H. Rehman and M. Niamatullah. 2010. Effect of different pollination techniques on fruit set pomological characters and yield of Dhakki date palm (Phonex dactylifera L) in Dera Ismail Khan, KP. Sarhad. J. Agric., 26 (4): 515-51

Khalifa, A.S.; A.I. El-Kady; K.M. Abdalla and A.M. El-Hamdy (1987). Influence of thinning patterns and leaf/bunch ratio on "Zaghloul" dates. Ann. Agric. Sci., Fac. Agric., Ain Shams Univ., Cairo, Egypt. 32(1): 637-647.

Khayyat, M.; E. Tafazoli; S. Eshaghi and S. Rajaee (2007). Effect of nitrogen, boron, potassium and zinc sprays on yield and fruit quality of date palm. American Eurasian J. Agric. \& Environ. Sci., 2 (3): 289-296.

Marashi, S. and A. Mousavi (2007). Effect of different methods and degrees of fruit thinning on yield and fruit characteristics of Barhee date cultivar. Acta Hort. (ISHS) 736: 187-192.

Marzouk, H.M.; A.M. El-Salhy; H.A. Abdel-Galil and A.E. Mahmoud (2007). Yield and fruit quality of some date palm cultivars in response to some flower thinning rates. The 4th Symposium on date palm in Saudi Arabia. King Faisal Univ., Al-Hassa, 5-7 May, p: 110 . 
Mostafa R.A.A. and M.M. El Akkad (2011). Effect of fruit thinning rate on yield and fruit quality of Zaghloul and Haiany date palms. Australian J. of Basic and Applied Sciences, 5(12): 3233-3239

Mostafa, R.A.A. (1994). Effect of different pollination methods on improving productivity of certain date palm (Phoenix dactylifera L.) cultivars under Assiut conditions. Ph.D. Thesis, Fac. Agric., Assiut Univ., Egypt.

Moustafa, A.A. (1998). Studies on fruit thinning of date palm .The First International Conference on date palm Al-Ain United Arab Emirates, pp: 354-363.

Nirmaljit, K.; J.S. Josan and P.K. Monga (2006). Fruit thinning of dates in relation to fruit size and quality. Abstract of the Third International Date Palm Conf. Feb. $19^{\text {th }}-21^{\text {th }}$, Abu Dhabi, United Arab Emirates.

Snedecor, G.W. and W.G. Cochran (1990). Statistical Methods $7^{\text {th }}$ ed. Iowa State Univ. Press. Ames.

Tavakkoli, A.; E. Tafazoli and M. Rahem (2006). Comparison of hand versus chemical thinning on quality and quantity of fruits and alternate bearing of "Shahani" date (Phoenix dactylifera $\mathrm{L}$.). Abstract of the Third International Date Palm Conf. Feb. $19^{\text {th }}-21^{\text {st }}$, Abu Dhabi, United Arab Emirates. 


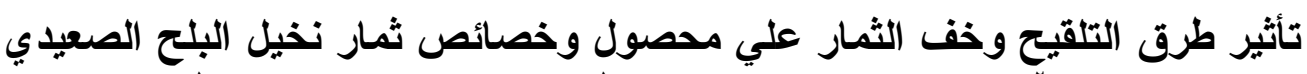

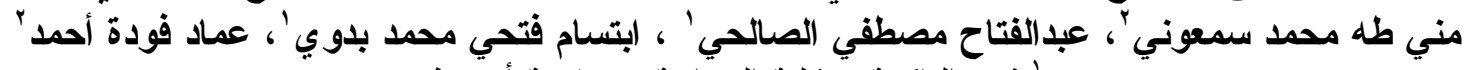

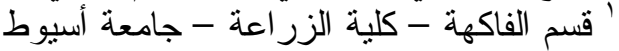

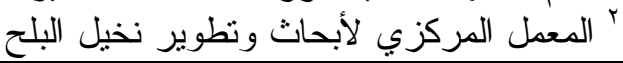

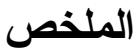

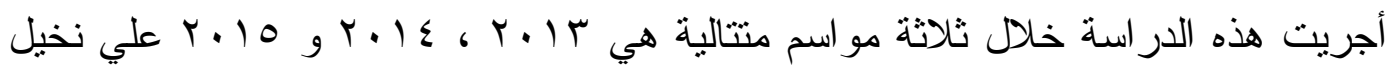

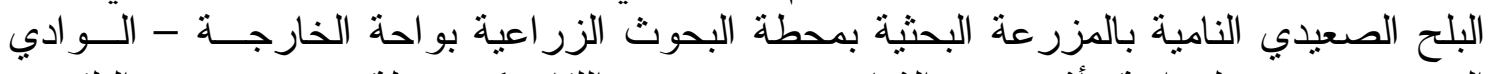

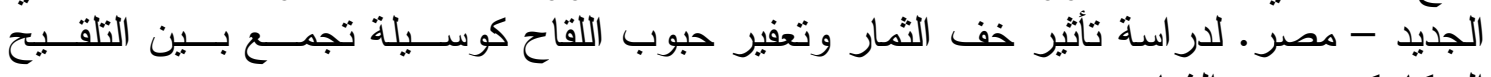

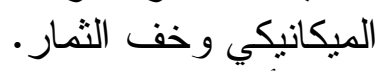

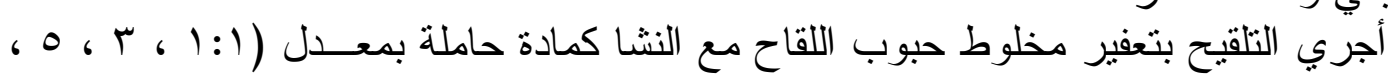

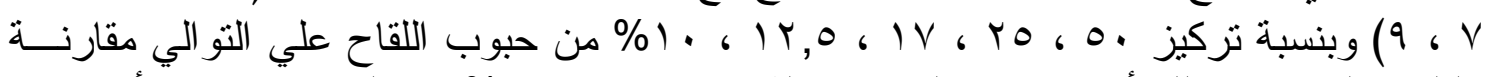

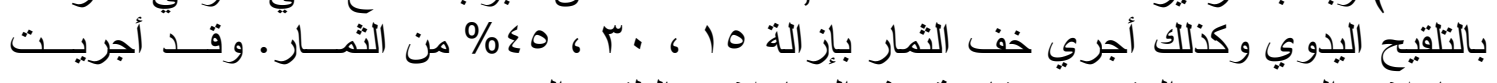

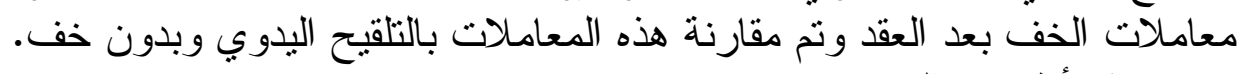

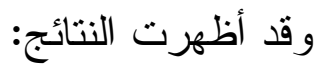

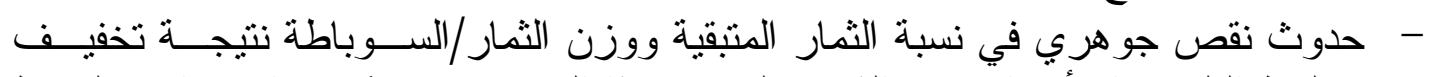

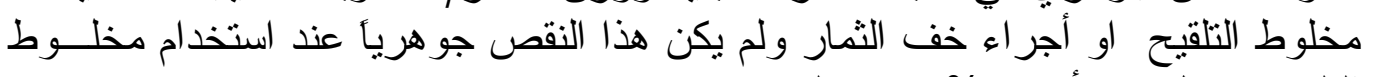

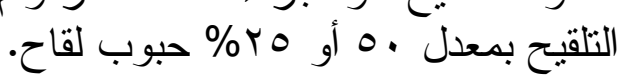

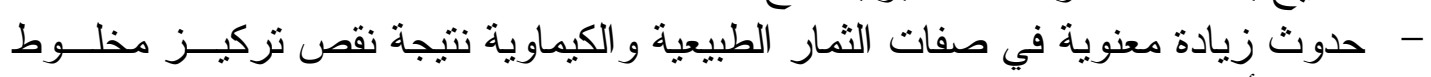

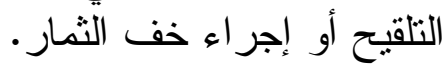

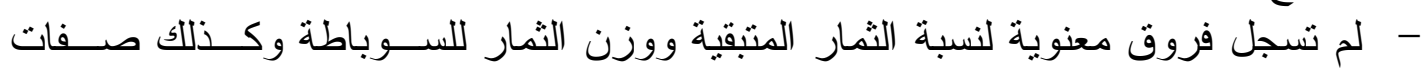

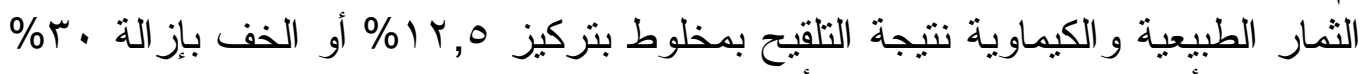

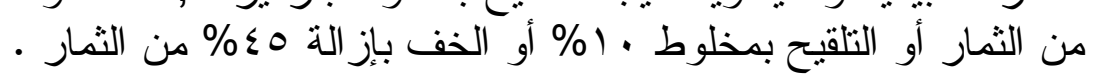

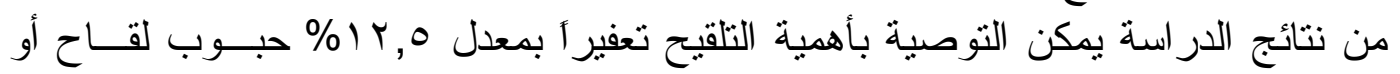

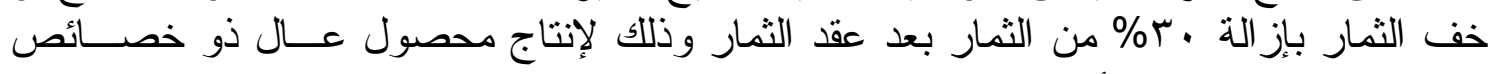

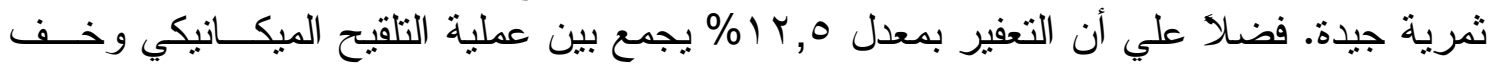

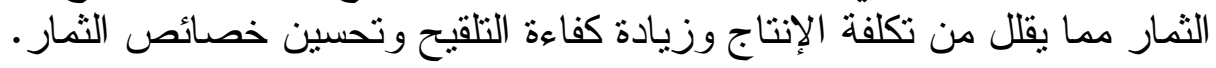

